\title{
An Explanation of Yield Differences in Three Potato Cultivars
}

\author{
J. S. Oliveira,* H. E. Brown, A. Gash, and D. J. Moot
}

\begin{abstract}
Under ideal growing conditions, yield is the product of intercepted photosynthetically active radiation $\left(\mathrm{PAR}_{\mathrm{i}}\right)$ and its conversion efficiency to dry matter (radiation use efficiency, RUE). For potato (Solanum tuberosum L.) the ability of the leaf to convert the $\mathrm{PAR}_{\mathrm{i}}$ into carbohydrates (source) and the storage capacity of the tubers (sink) affect the potential growth of individual tubers and therefore crop yield. This study describes these mechanisms for three commercial potato cultivars (Bondi, Fraser, and Russet Burbank) grown in non-limiting field conditions. At final harvest Bondi had the largest tuber yield and produced heavier but fewer tubers compared with Fraser and Russet Burbank. All crops had similar total accumulated radiation interception $\left(R_{\text {cum }}\right)$, and yield differences were explained by the RUE which was highest for Bondi, lowest for Fraser, with Russet Burbank intermediate. Fraser had the lowest rate of canopy senescence, maintained the lowest specific leaf area (SLA) for most of the period of tuber bulking and maintained the highest dry matter (DM) allocated to leaves at the end of the tuber filling phase. Throughout the crop growing period Bondi had a larger tuber sink compared with Fraser and Russet Burbank. These results suggest that potato tuber production was limited by the "sink strength" and RUE in the lower yield varieties. The larger sink in Bondi, caused by shorter stolons, enabled higher rates of tuber filling which produced the largest tubers in the middle node positions and the highest average tuber weight per plant among these cultivars.
\end{abstract}

\section{Core Ideas}

- The tuber yield of three potato cultivars was compared.

- Yield differences were not determined by total intercepted radiation.

- Low tuber sink strength and a low radiation use efficiency were detrimental to tuber yield.

- Leaf photosynthesis down regulation was linked to specific leaf area and canopy longevity.

- Final stolon length was the first vegetative signal of tuber sink strength during plant growth.

Published in Agron. J. 108:1-13 (2016)

doi:10.2134/agronj2015.0486

Received 30 Sept. 2015

Accepted 29 Mar. 2016

Available freely online through the author-supported open access option

Copyright (C) 2016 American Society of Agronomy

5585 Guilford Road, Madison, WI 53711 USA

This is an open access article distributed under the CC BY-NC-ND

license (http://creativecommons.org/licenses/by-nc-nd/4.0/) otato is a staple crop worldwide, ranking fourth after maize (Zea mays L.), rice (Oryza sativa L.), and wheat (Triticum aestivum L.). As potato consumption increases there is a need to understand the mechanisms that drive its yield. However, the origins of yield differences are rarely made clear in cultivar comparisons (Van Der Zaag and Doornbos, 1987) and breeding programs.

Potato crop growth and tuber yields have been linked to the duration of the growth cycle, which depends on climate, cultivar, and crop management (Kooman et al., 1996a, 1996b). Therefore, assuming optimum crop management, differences in tuber yield among potato cultivars can be explained by differences in accumulated intercepted radiation, the utilization coefficient of foliage followed by DM distribution within the plant (Van Der Zaag and Doornbos, 1987). Indeed, the amount of radiation intercepted by a crop and the RUE provide a useful basis for investigating yield variation (Monteith, 1977). From this concept, a simple model to express potato DM growth has been reported (Jamieson et al., 2004) as:

$$
Y=\int_{\mathrm{em}}^{t}\left(R_{\mathrm{o}} \times R / R_{\mathrm{o}} \times \mathrm{RUE}\right) \times \mathrm{HI}
$$

where $Y$ is the tuber yield, $R_{\mathrm{o}}$ is the daily incident solar radiation received, $R / R_{\mathrm{o}}$ is the daily fraction of $R_{\mathrm{o}}$ which is intercepted by the canopy ( $R$ being the daily average radiation intercepted by the plant), and RUE is the overall photosynthetic efficiency of the crop (i.e., the efficiency of conversion of radiant to chemical potential energy). The $\mathrm{HI}$ is the fraction of the dry matter produced which is allocated to the tubers. The integration of these components over time ( $t$; days) from crop emergence (em) allows the description of biomass accumulation in terms of plant development processes.

This is a common approach used for potato yield analysis (Van Der Zaag and Doornbos, 1987; Spitters et al., 1989; Ellissèche and Hoogerndoorn, 1995) and simulation models of potato yield (Jamieson et al., 2004). The amount of radiation intercepted by the crops is reportedly the central component to explain

J.S. Oliveira, A. Gash, and D.J. Moot, Faculty of Agriculture and Life Science, P.O. Box 85084, Lincoln University, 7647, Canterbury, NZ; H.E. Brown, The New Zealand Institute for Plant and Food Research Ltd., Private Bag 4604, Christchurch, NZ. ${ }^{*}$ Corresponding author (juliano.oliveira@lincolnuni.ac.nz).

Abbreviations: DAP, days after planting; DM, dry matter; LGR, linear growth rates; $R_{\text {cum }}$, accumulated radiation interception; $R /$ $R_{\mathrm{o}}$, radiation interception or fraction of canopy ground cover; RUE, radiation use efficiency; SLA, specific leaf area. 
cultivar yield differences. However, there has been little potato research to define the ideal canopy structure for obtaining high and stable tuber yields (Schittenhelm et al., 2006). Differences in RUE among genotypes are usually unclear (Jefferies, 1993) and therefore it is often assumed as a constant value in potato simulation models (Griffin et al., 1993; Van Keulen and Stol, 1995). This simplification may compromise the precision of yield simulations when RUE deviates from a fixed value. Moreover, there is little information on the partitioning of photosynthates within the plant organs before and after the tubers become the largest sink in the plant. This represents another weakness in potato yield models. Kooman and Rabbinge (1996), for example, suggested that leaf production and longevity in potato crops are regulated by tuber sink strength. This suggests the importance of accounting for the impacts of sink strength on mechanistic potato modeling approaches. In fact, potato models frequently consider a phase when leaf growth and tuber bulking overlaps (Griffin et al., 1993; Kooman and Haverkort, 1995). During this period there is competition between foliage and tubers for assimilates. Therefore, it seems that an accurate description of source capacity and sink demand during this phase is important to understand potato crop physiology that could then be utilized to inform potato crop models and improve understanding of potato yields.

In this research, aboveground and belowground growth behavior of three potato cultivars are reported from field grown conditions. Comparisons of canopy development and, radiation interception, RUE, and DM partitioning to tubers and aerial organs are made to explain yield differences among cultivars. The relationship between individual tuber growth, node position, and stolon length, to which the tuber is attached, are also described.

\section{MATERIALS AND METHODS}

\section{Experimental Site and Meteorological Data}

The experiment was located in Canterbury, NZ (43⒊ $9^{\prime} \mathrm{S}$ and $\left.172^{\circ} 28^{\prime} \mathrm{E}\right)$. The paddock was in grazed pasture prior to the establishment of these potato crops. The soil is classified as a Templeton silty loam (or Udic Ustrochrept), Typic immature pallic soil, characterized as moderately deep $(45-90 \mathrm{~cm})$ with $102 \mathrm{~mm}$ available water in the top $0.6 \mathrm{~m}$.

Hourly values of maximum and minimum air temperatures and daily values of total radiation, actual rainfall, and evapotranspiration were obtained from data recorded at Broadfields Meteorological Station at Lincoln, Canterbury, NZ, located within $1.5 \mathrm{~km}$ from the experimental field. Mean monthly air temperature $\left({ }^{\circ} \mathrm{C}\right)$ ranged from 6 to $15^{\circ} \mathrm{C}$ during the experiment. The largest daily temperature difference occurred in November when the temperature ranged from 0 to $27^{\circ} \mathrm{C}$ (see Appendix A for details of daily minimum, maximum, and average air temperatures). The average monthly solar radiation ranged from $6.5 \mathrm{MJ} \mathrm{m}^{-2}$ for the month of May to $24 \mathrm{MJ} \mathrm{m}^{-2}$ for the month of November.

\section{Cultivars}

Two New Zealand grown cultivars of contrasting yields (Bondi and Fraser) and an internationally known standard (Russet Burbank) were used. These are all maincrop potato cultivars with an indeterminate growth habit.

\section{Seed Potato Origin, Storage, and Field Planting}

A total of 348 seed potatoes of each cultivar were collected from three different locations in mid-Canterbury and then stored under commercially accepted best practices in a cooler $\left(4^{\circ} \mathrm{C}\right)$ for $\sim 14 \mathrm{~d}$ after each crop was machine harvested. On 9 Sept. 2011 ( 28 d before planting) all seed potatoes were moved from the cooler into a shed (at ambient temperature and no light) to break dormancy. The mean seed potato weight was similar to commercial standards ( $115 \mathrm{~g}$ for Bondi, $\sim 80 \mathrm{~g}$ for Fraser and $\sim 115 \mathrm{~g}$ for Russet Burbank) and these seed potato weight differences are not expected to contribute to differences in crop yields (Oliveira et al., 2014; Oliveira, 2015).

A field experiment was established to compare the growth and development of each crop under optimum conditions on 0.031 ha. Best management practices were applied to keep the crop free of weeds, pests, and diseases and supplied with adequate nutrients and water (see Appendix B for details). On 14 Oct. 2011 the seed potatoes were hand planted and mechanically molded to $\sim 300 \mathrm{~mm}$ of depth. Plots were $21 \mathrm{~m}$ long and $1.6 \mathrm{~m}$ wide with two rows. Plant spacing was $0.35 \mathrm{~m}$ within the same row and $0.8 \mathrm{~m}$ between rows, with each cultivar planted in three replicates following a completely randomized design. Plots were separated by a $1.6 \mathrm{~m}$ empty row. In addition, two buffer plants were used at the end of each plot row.

\section{Morphological Definitions and Crop Measurements}

In this paper a main stem refers to the "true stem" developed directly from the seed potato as defined by Vos (1995) and Struik and Ewing (1995). Belowground level, each main stem can develop stolons and belowground lateral branches (BGLB) from its axillary nodes. Stolons are diageotropic stems with elongated internodes and may bear tubers. The report of tuber length at the node level will refer to individual tubers produced at a certain node position on the main stem (belowground level). Aboveground level, the same main stem produces a leaf and potentially a branch at each node (first level of foliage) which terminates in an inflorescence (first inflorescence). Lateral branches are also produced on these main stems above the ground level. These aboveground lateral branches can arise on the second (n-1) and third (n-2) axillary nodes below the first inflorescence (apical lateral branches) and at lower node positions (e.g., n-13 and n-14; basal lateral branches) of the main stems. These aboveground lateral branches represent the second level of growth that can also terminate in an inflorescence (second inflorescence). Later, third and higher levels may appear (refer to Appendix C for schematic illustration of the potato plant organs).

In this study the top most aboveground lateral branch (n-1 or n-2) to appear on each new level of growth was considered as a continuation of the main stem. Therefore, values reported for the main stem measurements aboveground level (e.g., number of leaves, leaves DM, petiole DM and "stem" DM) include the main higher order lateral stems. The term aboveground "stem" will be used to designate any stem above the ground level without petioles, leaves, and flowers.

The date of $75 \%$ emergence was determined in all replicates by counting the number of plants emerged over the whole plot every second day. A plant was defined as emerged at the first appearance of a leaf above the ground (Searle, 1999). All DM 
measurements were obtained after drying the samples in a forced air oven $\left(65-70^{\circ} \mathrm{C}\right)$ to constant weight.

\section{Fractional Radiation Interception}

A multispectral radiometer system (CROPSCAN, Inc., Rochester, $\mathrm{MN}$ ) was used to estimate the percentage of canopy cover or fraction of radiation interception $\left(R / R_{\mathrm{o}}\right)$ at a 7 to 20 dinterval from 18 Nov. 2011 to 13 Apr. 2012. Reflectance of the radiation in the visible (VIS; $400-700 \mathrm{~nm}$ ) and in the near infrared (NIR; 750-850 nm) wavelengths was combined to the normalized difference vegetation index (NDVI) to give the canopy intercepted radiation $(R)$ at each CROPSCAN reading. These values were later combined with the total incident radiation $\left(R_{\mathrm{o}}\right)$ to give the fraction of radiation interception by the crop, or crop canopy $\operatorname{cover}\left(R / R_{\mathrm{o}}\right)$ (Tucker, 1979; Gamon et al., 1995). Appendix D has more details on NDVI measurements and calculations.

\section{Sampling}

Six plants were sampled from each plot (three plants on each row). The plants were hand lifted using a fork on 11 occasions $(40,47,53,61,67,75,82,97,111,125$, and 138 days after planting [DAP]) from 23 Nov. 2011 to 29 Feb. 2012. The first to the fifth samplings were scheduled to occur between the phenological stages 40 to 41 (BBCH-scale), the 6th to the 10th samplings between 41 and 47 (BBCH-scale) and the 11th sampling on 48 (BBCH-scale). The samples were taken sequentially from the western end of each plot. To minimize any confounding effect of canopy competition among plants, the first plant of the row was skipped at each sampling event. The plants were hand lifted with care using a fork to preserve the stolons attached to the tubers and to the main stems. Later the bulk of soil around the belowground organs was removed by hand. A subsample of one main stem of each plant (with all its aboveground and belowground organs) was randomly selected from each one of the six plants sampled. The subsample was then separated into aboveground and belowground organs, and DM recorded.

\section{Aboveground Organs}

The measurements taken from the subsample main stems included individual green leaf area, individual green leaf DM (without the petiole), petiole DM and main stems DM.

To measure individual leaf area a Li-Cor 3100 Area Meter (LI-COR, Lincoln, NE) was used. The leaves from each individual node of the main stem were grouped from the six subsamples before going through the leaf area meter.

\section{Belowground Organs}

For the whole sampling period, the belowground sample DM (including stolons and excluding roots) was measured. In addition, for all 11 sampling events, the tubers collected from the destructive sample (including the tubers from the subsamples) were washed and left to air dry before being weighed fresh (FM). Then, the tubers were dried to obtain DM on each sample.

A ruler was used to take some measurements on the subsample. These measurements focused on stolons grown on the individual nodes of the belowground main stem and on the tubers grown from these stolons. To achieve this, each node position was numbered from top (near ground surface) to bottom on the belowground main stem profile. The nodes were then measured for stolon length and visually assessed for tuber initiation status. The stolons were also classified according to their origin: primary and lateral stolons were those arising from primary and associated axillary nodes at belowground nodes, respectively, while stolons originating as branches of primary stolons or secondary stolons are referred to as "branch" stolons (Cother and Cullis, 1985). Tuber initiation was considered from when the tip of the stolon started swelling ( $2 \mathrm{~mm}$ of width). From the swelling stage onward the potato crops were graded into size classes of 1 $\mathrm{cm}$. These measurements at the individual node position level were last taken on 4 Jan. 2012 for Bondi and on 19 Jan. 2012 for Fraser and Russet Burbank. After those dates the tubers detached easily from stolons and, therefore it was impossible to lift the entire crop with all of the tubers still attached to each stolon, to be completely sure of its origin.

On 18 Apr. 2012 the three cultivars were desiccated after they all had reached more than $50 \%$ of canopy senescence. The experiment ended when the potato plants were mechanically harvested on 2 May 2012 using a single row digger. On this occasion, around 36 plants (or $30 \%$ of the total number of plants sown per plot) were harvested from each plot.

\section{Calculations}

\section{Tuber Yield}

The final tuber yield distribution of each cultivar was calculated based on the accumulated proportion of final yield. To calculate the accumulated proportion of final yield the tubers were sorted into weight grades of $50 \mathrm{~g}$. The sum of weights within each grade divided by the total FM (of all tubers) gave the proportion per grade. The sum of grade proportions from the lowest $(0-50 \mathrm{~g})$ to the highest $(1050-1100 \mathrm{~g})$ grade established the accumulated proportion which ranged from zero to one.

Accumulated tuber DM yields (measured from 23 Nov. 2011 to final harvest) were fitted against DAP and growing degree days (GDD) using a Gompertz curve:

$$
y=a \times \exp \{-\exp [-b \times(x-c)]\}
$$

where $y$ is the tuber mass, $a$ is the maximum tuber mass, $b$ is the relative growth at the inflection point and $c$ is the time (e.g., GDD) at the inflection point. The time when $5 \%$ and 95\% of the final tuber DM was also calculated for each plot based on the curve estimates. Linear growth rates (LGR) and tuber DM ha ${ }^{-1}{ }^{\circ} \mathrm{Cd}^{-1}$ were also calculated for each plot of each cultivar. The LGR was calculated by fitting a linear regression between accumulated tuber DM and GDD using all datapoints within the range of 5 and $95 \%$ of the maximum yield for each cultivar (Brown, 2004).

\section{Growing Degree Day Calculation}

Daily GDD $\left({ }^{\circ} \mathrm{Cd}\right)$ was calculated using daily average air temperatures $\left(\mathrm{T}_{\text {mean }}\right)$ after crop emergence. Daily average air temperature was measured using the average of hourly air temperatures above a threshold $\left(\mathrm{T}_{\mathrm{b}}\right)$ of $2^{\circ} \mathrm{C}$ (Oliveira, 2015). Then the cumulative GDD was calculated by the sum of the daily GDD. A linear function of temperature accumulation with a rate of $1.0^{\circ} \mathrm{Cd}^{\circ} \mathrm{C}^{-1}$ above $\mathrm{T}_{\mathrm{b}}$ was applied. Since the $\mathrm{T}_{\text {mean }}$ was never above $25^{\circ} \mathrm{C}$ during the field experimental period, GDD did not have to be corrected for supra optimal temperatures. 
Fractional Radiation Interception, Leaf Area Index, and Extinction Coefficient

The $R / R_{\mathrm{o}}$ was measured and combined with the total incident radiation $\left(R_{\mathrm{o}}\right)$ from the meteorological station to calculate the radiation intercepted in $\mathrm{MJ} \mathrm{m}{ }^{-2}$ by the canopy. Daily values of radiation interception $\left(R_{\text {daily }}\right)$ were estimated with a Piece-wise regression fitted to each individual plot using a series of 16 measurements taken from 15 Nov. 2011 to 13 Apr. 2012. The regressions were fitted against DAP and GDD. The Piece-wise regression consisted of a three phase linear model of canopy formation. Immediately after crop emergence, the phase of canopy growth happened concomitant to the $R / R_{\mathrm{o}}$ rise at a linear rate of increase. Then the crop had a constant canopy phase when the crop was at maximum ground cover $\left(R / R_{\mathrm{o} \max }\right)$. The final phase characterizes the canopy senescence in which $R / R_{\mathrm{o}}$ decreases at a linear rate.

The total accumulated radiation interception $\left(R_{\text {cum }}\right)$ was calculated by integrating $R_{\text {daily }}$ from crop emergence (em) to crop desiccation (des), on 18 Apr. 2012, according to Eq. [3]:

$$
R_{\text {cum }}=\int_{\text {em }}^{\text {des }} R / R_{\text {odaily }} \times R_{\text {odaily }}
$$

where, $R_{\text {odaily }}$ is the daily average total incident radiation.

Leaf area index (LAI) was estimated from leaf DM using the concept of specific leaf area (SLA; $\mathrm{m}^{2} \mathrm{~kg}^{-1} \mathrm{DM}$ of leaf). The extinction coefficient $(k)$ was used to describe the canopy architecture of the crops. The $k$ value was calculated from the regression of the natural log of the $R / R_{\mathrm{o}}$ by the crop against LAI.

\section{Radiation Use Efficiency}

Radiation use efficiency was calculated from the total dry matter $\left(\mathrm{DM}_{\text {total }}\right)$ accumulated in the entire plant (which included aboveground and belowground parts of the crop but excluded roots). The calculation fitted a linear regression from the origin, to the plot averages of $\mathrm{DM}_{\text {total }}$, against $R_{\text {cum }}$ from 14 Oct. 2011 to 29 Feb. 2012.

\section{Fraction of Total Dry Matter Partitioned in the Tubers (Harvest Index)}

The fraction of total DM partitioned in the tubers or crop harvest index ( $\mathrm{HI})$ was calculated by dividing the DM accumulated in the tuber by the $\mathrm{DM}_{\text {total }}$.

\section{Leaves, Petioles, and Aboveground Stems Dry Matter}

The proportion of DM allocated to leaves, petioles, and aboveground main stems was estimated from the subsample measurements and then these were multiplied by the total DM of the sample (six plants $=\sim 1.7 \mathrm{~m}^{2}$ ) to give the DM of leaves per plant, petioles per plant, and aboveground stems per plant, respectively.

\section{Data Analysis}

Data were analyzed using GenStat version 14 (VSN International). Significant differences among the treatments were determined by ANOVA according to the completely randomized design. Standard error of differences of means (SEM) were used to evaluate least significant differences (LSD) at the $\alpha=0.05$ probability level for means separation of the cultivars. Linear and nonlinear regressions were fitted between dependent and explanatory variables. When appropriate, a Piece-wise regression was fitted using SIGMAPLOT version 10.0 (SPSS Inc.). Regression coefficients, standard errors of coefficients and coefficients of determination are reported. When values are significant at $\alpha=0.1$ but not $\alpha=0.05$, results are reported as a trend.

\section{RESULTS}

Bondi had a larger $(P<0.067)$ tuber DM yield $\left(\sim 17.0 \mathrm{t} \mathrm{ha}^{-1}\right)$ than either Fraser $\left(\sim 13.3 \mathrm{t} \mathrm{ha}^{-1}\right)$ or Russet Burbank $\left(\sim 13.5 \mathrm{t} \mathrm{ha}^{-1}\right)$ at final harvest. This reflected the conservative tuber dry matter content (DM\%) among the cultivars during the whole growing season. For all cultivars tuber DM\% increase was described by a sigmoid curve from 15\% ( 50 DAP) to an asymptote at $26 \%$, from $\sim 140$ DAP until final harvest.

There was also a strong $\left(R^{2}>0.99\right)$ relationship between tuber DM and GDD accumulated from crop emergence (Fig. 1). Tuber DM increased consistently from $\sim 370^{\circ} \mathrm{Cd}$ (or $62 \mathrm{DAP}$ ), when $5 \%$ of the final tuber DM was reached in all cultivars, to $\sim 1400^{\circ} \mathrm{Cd}$ (or 140 DAP). At this point the three cultivars had attained $95 \%$ of the final tuber DM yield and therefore this was considered the final tuber yield (Fig. 1). The average rate of maximum tuber DM accumulation (LGR) was $20 \%$ higher $(P<0.02)$ for Bondi $\left(1.58 \mathrm{~kg} \mathrm{ha}^{-1}{ }^{\circ} \mathrm{Cd}^{-1}\right)$ than Fraser $\left(1.26 \mathrm{~kg} \mathrm{ha}^{-1}{ }^{\circ} \mathrm{Cd}^{-1}\right)$. Refer to Appendix E for LGR linear equations.

Bondi had a higher total yield compared with Russet Burbank and Fraser, but these last two produced 57 and $70 \%$, respectively, more $(P<0.01)$ tubers than Bondi (27.8 tubers $\mathrm{m}^{-2}$ ). (Refer to Appendix F for marketable tuber grade yields and yield numbers.)

Figure 2 shows the accumulated proportion of yield screened into 50 g grades. Fraser and Russet Burbank showed similar yield distributions with $75 \%$ of their FM yield in potatoes of grades under $250 \mathrm{~g}$. In contrast, potatoes that weighed less than $250 \mathrm{~g}$ accounted for only $25 \%$ of the Bondi yield. For Bondi, $50 \%$ of

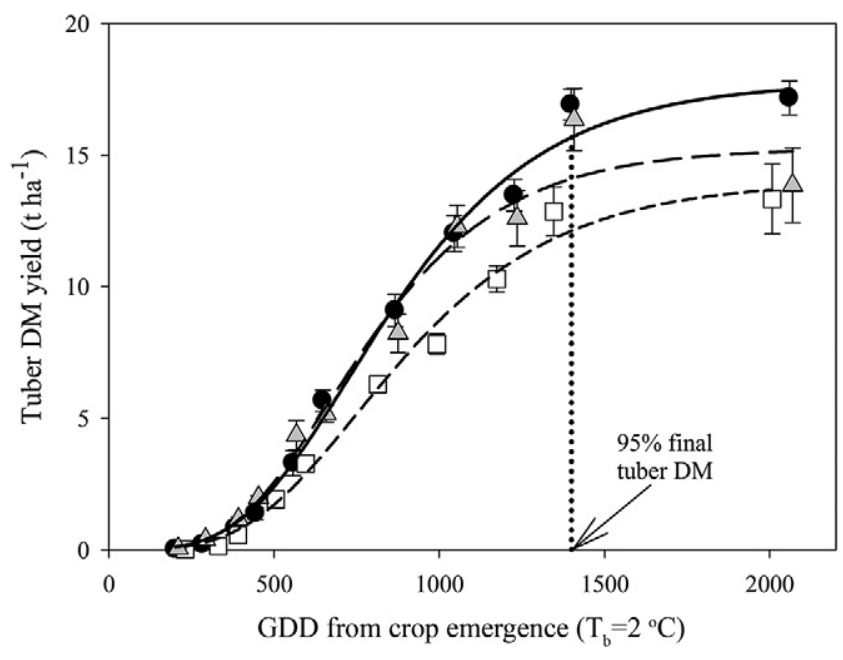

Fig. I. Average potato dry matter (DM) against growing degree days (GDD, $\mathrm{T}_{\mathrm{b}}=2^{\circ} \mathrm{C}$ ) for Bondi (closed circle), Fraser (open square) and Russet Burbank (shaded open triangle) crops planted on 14 Oct. 20II at Lincoln, Canterbury, NZ. Gompertz curves are: Bondi: $y=17.8 \times \exp \left\{-\exp \left[-3.07 \times 10^{-3}(x-726)\right]\right\}$; Fraser: $y=14.0 \times \exp \left\{-\exp \left[-2.97 \mid \times 10^{-3}(x-750)\right]\right\}$ and Russet Burbank: $y=15.3 \times \exp \left\{-\exp \left[-3.46 \times 10^{-3}(x-667)\right]\right\}$. All $R^{2}>$ 0.99 . Vertical dotted line represents the time of $95 \%$ final tuber DM for all cultivars. 
yield was in the 250 to $450 \mathrm{~g}$ range and $25 \%$ in tubers larger than $400 \mathrm{~g}$. The average FM tuber weight was higher $(P<0.001)$ for Bondi (238 g) than Fraser and Russet Burbank (114 \pm 29$)$.

The three cultivars had $100 \%$ emergence. Bondi and Russet Burbank crops emerged $\sim 30$ DAP with Fraser $5 \mathrm{~d}$ later $(P<0.001)$.

Figure 3 shows the Piece-wise models used to predict the fraction of radiation intercepted $\left(R / R_{\mathrm{o}}\right)$ during the crop growing season for each cultivar. These explained over $97 \%$ of the variance. The maximum $R / R_{\mathrm{o}}$ was higher $(P<0.013)$ for Bondi and Fraser ( 91\%) than Russet Burbank. Canopy ground cover increased at a rate of $\sim 0.20 \%{ }^{\circ} \mathrm{Cd}^{-1}\left(\sim 2.20 \% \mathrm{~d}^{-1}\right)$ for all crops. On average the canopy of the cultivars reached their maximum $R / R_{\mathrm{o}}$ after $\sim 500^{\circ} \mathrm{Cd}(\sim 73 \mathrm{DAP})$ and remained constant at this maximum for a further $\sim 840^{\circ} \mathrm{Cd}(\sim 62 \mathrm{~d})$. Russet Burbank had the fastest $(P<0.025)$ rate of senescence (decrease in green area; $0.15 \%{ }^{\circ} \mathrm{Cd}^{-1}$ or $1.60 \% \mathrm{~d}^{-1}$ ) and Fraser the slowest $\left(0.06 \%{ }^{\circ} \mathrm{Cd}^{-1}\right.$ or $\left.0.63 \% \mathrm{~d}^{-1}\right)$. However, $95 \%$ of the crops final tuber DM yield was reached soon after the canopies started senescing $\left(1350^{\circ} \mathrm{Cd}\right.$ or $\left.135 \mathrm{DAP}\right)$. Around that point the accumulated radiation interception was not different $(P<$ 0.14 ) among the cultivars and averaged $\sim 1650 \mathrm{MJ} \mathrm{m}^{-2}$ of total solar radiation.

There was no difference $(P<0.61)$ among the cultivars for the amount of radiation intercepted by the canopy per unit of LAI. The critical leaf area index $\left(\mathrm{LAI}_{\text {crit }}\right)$ calculated for when the crops intercepted $90 \%$ of the incoming radiation was 3.8 for an extinction coefficient $(k)$ calculated as 0.77 (refer to Appendix G).

The RUE was higher $(P<0.02)$ for Bondi $\left(1.24 \mathrm{~g} \mathrm{DM} \mathrm{MJ}^{-1}\right)$ than Fraser $\left(0.99 \mathrm{~g} \mathrm{DM} \mathrm{MJ}^{-1}\right)$, while Russet Burbank averaged $1.09 \mathrm{~g} \mathrm{MJ}^{-1}$ (Fig. 4).

The pattern of $\mathrm{HI}$ increase over time from planting to $\sim 1400^{\circ} \mathrm{Cd}$ accumulated from crop emergence was exponential for the three cultivars (Fig. 5). The HI was higher $(P<0.05)$ for Bondi and Russet Burbank than Fraser throughout the growth season. After $1400^{\circ} \mathrm{Cd}$ (around the time of $95 \%$ final tuber DM), as the three cultivars had begun to senesce, Fraser

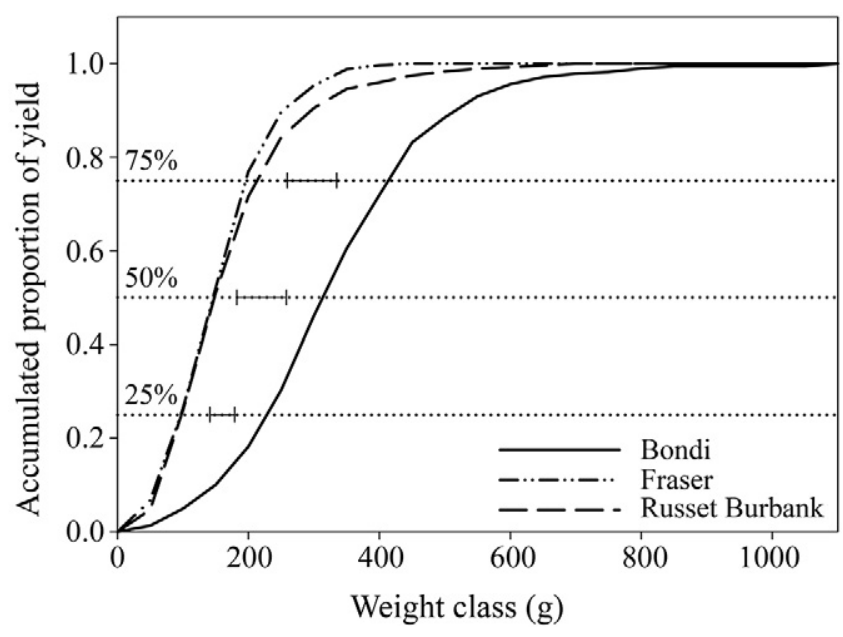

Fig. 2. Accumulated proportions of fresh matter yield against the weight classes at final harvest for Bondi, Fraser, and Russet Burbank potatoes. The crops were grown during the summer (October-May) in the years 20II-2012 at Lincoln, Canterbury, NZ. Horizontal dotted lines indicate the proportion of yield in each quartile. Bars are LSD $\alpha=0.05$ represented for the accumulated proportion quartiles.

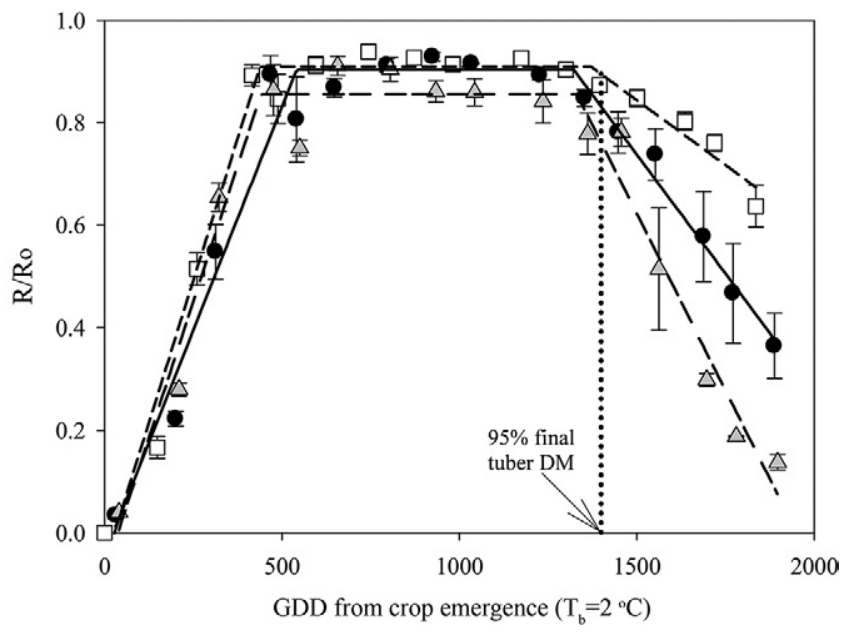

Fig. 3. Fraction of radiation interception $\left(R / R_{\mathrm{o}}\right)$ measured from 15 Nov. 2011 to 13 Apr. 2012 against growing degree days (GDD) from crop emergence measured in ${ }^{\circ} \mathrm{Cd}$ for Bondi (closed circle), Fraser (open square) and Russet Burbank (shaded open triangle) potato crops grown between $201 \mathrm{I}$ and 2012 . R/R from 0 (no cover) to I (I00\% cover). Bars represent the standard error above and below the mean values.

HI averaged 0.74 , which was lower $(P<0.002)$ compared with the values found for Bondi $(0.83 \pm 0.04)$ and Russet Burbank $(0.86 \pm 0.04)$.

The time of $50 \%$ fraction of dry matter partitioned into the tubers was different $(P<0.006)$ among cultivars. Bondi and Russet Burbank had $50 \%$ of their DM accumulated in the tubers at $\sim 510^{\circ} \mathrm{Cd}$ from crop emergence ( $\left.70 \mathrm{DAP}\right)$. However, Fraser reached this fraction $17 \mathrm{~d}$ later than Russet Burbank (or $\sim 665^{\circ} \mathrm{Cd}$ from crop emergence).

The leaves accounted for up to $\sim 80 \%$ of the aboveground DM (Fig. 6). In most cases, the cultivars increased the DM allocated to their leaves with up to $950 \pm 50^{\circ} \mathrm{Cd}$ accumulated from crop emergence. From then on, leaf DM decreased for Bondi and Russet Burbank, but was relatively constant for

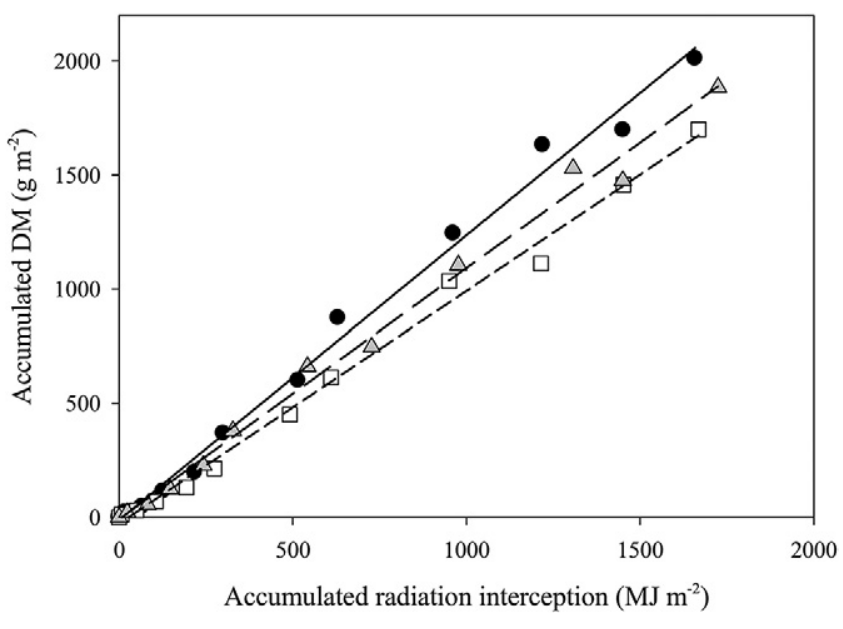

Fig. 4. Accumulated total dry matter (DM) against accumulated total solar radiation interception $\left(R_{\text {cum }}\right)$ for Bondi (closed circle), Fraser (open square) and Russet Burbank (shaded open triangle) potato crops planted on 14 Oct. 20II. A regression line was fitted to the accumulated total DM against $R_{\text {cum }}$ for Bondi: $y=$ I.24x (0.02), $R^{2}=0.99$; Fraser: $y=0.99 x(0.02), R^{2}=0.99$; Russet Burbank: $y=1.09 x(0.02), R^{2}=0.99$. Bracketed values represent SEM for coefficients. 


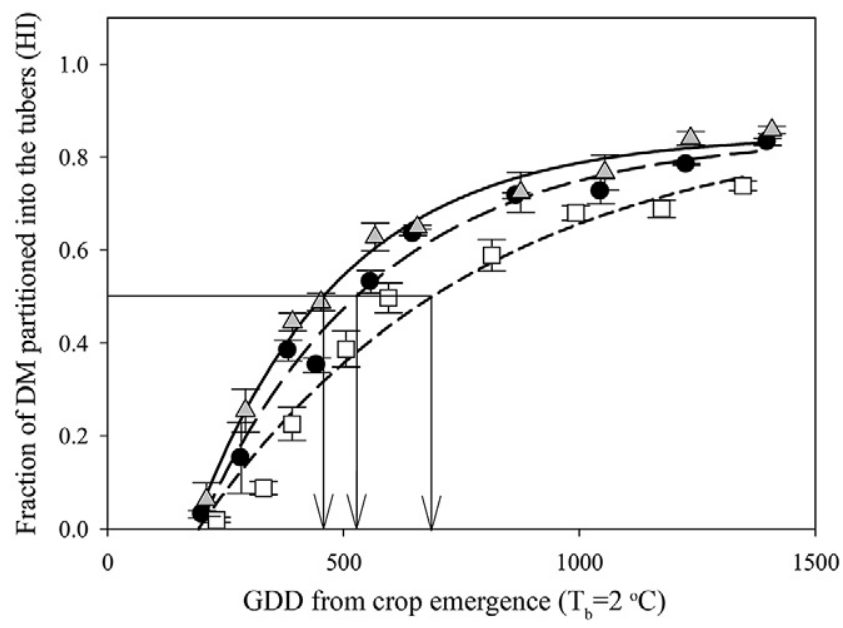

Fig. 5. Fraction of dry matter (DM) partitioned to tubers against cumulative growing degree days (GDD) for Bondi (closed circle), Fraser (open square) and Russet Burbank (shaded open triangle) crops measured from 14 Oct. 2011 to 29 Feb. 20II. Bars represent the standard error above and below the mean values. The exponential curves were fitted to average values for Bondi: $y=$ $-0.57(0.13)+1.42(0.10) \times\{1-\exp [-0.003(0.0004) x]\}, R^{2}=$ 0.99; Fraser: $y=-0.34(0.10)+1.22(0.08) \times\{1-\exp [-0.002$ (0.0005) $x], R^{2}=0.97$ and Russet Burbank: $y=-0.68(0.1 \mathrm{I})+\mathrm{I} .53$ $(0.10) \times\left\{I-\exp [-0.003(0.0003) x], R^{2}=0.99\right.$. Bracketed values represent SEM for coefficients. Arrows indicate the time of $50 \%$ fraction of dry matter partitioned into the tubers.

Fraser. The decrease represented a leaf DM reduction of $~ 23$ and $\sim 13 \mathrm{~g} \mathrm{plant}^{-1}$ for Bondi and Russet Burbank, respectively. At $1400^{\circ} \mathrm{Cd}$ the percentage of the aboveground green $\mathrm{DM}$ allocated to the leaves was highest $(P<0.001)$ for Fraser $(80 \%$ $\pm 3.5)$ compared with Bondi $(57 \pm 3.5 \%)$ and Russet Burbank $(50.0 \pm 3.5 \%)$.

All crops had a constant increase in the DM allocated in the aboveground stems up to 120 DAP. At 138 DAP Russet Burbank had the highest $(P<0.001)$ percentage of its green aboveground DM allocated in the stems $(35 \pm 1.7 \%)$ compared with Bondi $(26 \pm 1.6 \%)$ and Fraser (18.5 $\pm 1.7 \%)$. Petioles were the lowest aboveground organ pool for DM. These accounted for less than $\sim 15$ g per plant in all three cultivars.

Specific leaf area (SLA, $\mathrm{m}^{2} \mathrm{~kg}^{-1}$ ) change is presented in Fig. 7 as a mean of all leaves measured on the second and third main stem levels. Bondi and Russet Burbank had similar SLA

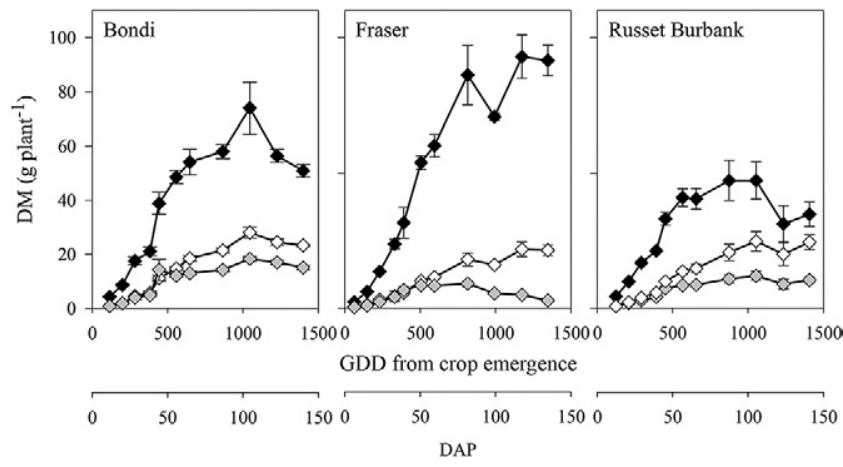

Fig. 6. Pattern of plant dry matter (DM) accumulation in leaf (closed diamond), petiole (shaded open diamond) and stem (open diamond) above the ground level for Bondi, Fraser, and Russet Burbank crops against growing degree days (GDD, $T_{b}=2^{\circ} \mathrm{C}$ ) and days after planting (DAP) on 14 Oct. 20II. Bars represent the standard error above and below the mean values. measured from 400 to $1500^{\circ} \mathrm{Cd}$. In contrast, Fraser had the lowest values (thicker leaves) for most of this period. Bondi and Russet Burbank reached a maximum of $\sim 24 \mathrm{~m}^{2} \mathrm{~kg}^{-1}$ at $650^{\circ} \mathrm{Cd}$ while Fraser attained a maximum of $\sim 16 \mathrm{~m}^{2} \mathrm{~kg}^{-1}$ around that time. In all three cultivars SLA declined after reaching its maximum, but this was less evident in Fraser. Around the time when all cultivars had reached $95 \%$ of their total final tuber yield, Bondi and Fraser had a similar SLA of $\sim 13.5 \mathrm{~m}^{2} \mathrm{~kg}^{-1}$.

The pattern of stolon distribution displayed in Fig. 8 shows that the shorter stolons were concentrated on the lower nodes $(>6)$ in all cultivars. Fraser produced the longest $(P<0.001)$ stolons at the upper middle nodes (1-4). After 40 DAP Russet Burbank had stolons at their maximum length. The same happened to Bondi after 47 DAP. However Fraser maintained stolon growth until $\sim 61$ DAP. The sum of all stolon lengths was calculated at $82 \mathrm{DAP}$ to measure the relative distance between phloem and sink. The summed values 82 DAP (Fig. 8) were highest $(P<0.005)$ for Fraser $(354 \mathrm{~mm})$ and lowest for Russet Burbank $(190 \mathrm{~mm})$ with $256 \mathrm{~mm}$ for Bondi.

The pattern of tuber size distribution at each node position is shown for Bondi, Fraser, and Russet Burbank in Fig. 9. The average values presented correspond only to tubers formed on the primary stolons, since lateral and branched stolons represented $<5 \%$ of the proportion of tuber initiation.

At 40 DAP only Russet Burbank had signs of tuber initiation on tubers positioned in nodes three, four, and five. Seven and $13 \mathrm{~d}$ later these node positions showed signs of initiation in Bondi (47 DAP) and Fraser (53 DAP), respectively. In the three cultivars the top (node one) and bottom nodes had a low (near to zero) chance of initiating tubers. At $82 \mathrm{DAP}$ the most likely (chance $>70 \%$ ) node positions to initiate a tuber were the third to sixth belowground nodes for Fraser and Russet Burbank, and the fourth to ninth belowground nodes for Bondi. At 82 DAP Bondi had more tubers grown to a longer size (e.g., tubers $>4 \mathrm{~cm}$ in length) compared with Fraser and Russet Burbank.

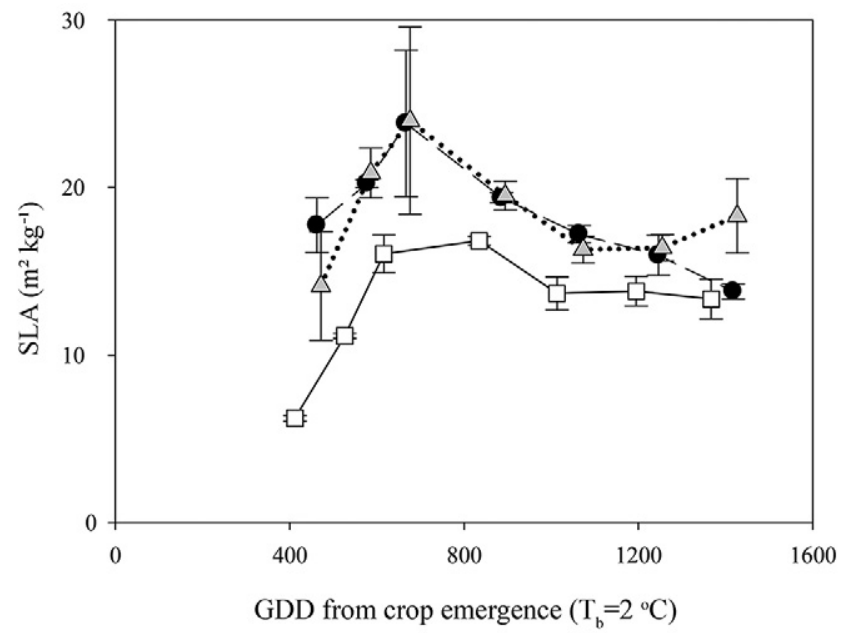

Fig. 7. Mean specific leaf area (SLA, $\left.\mathrm{m}^{2} \mathrm{~kg}^{-1}\right)$ of the second and third levels of the main stem against growing degree days (GDD) from crop emergence measured in ${ }^{\circ} \mathrm{Cd}$ for Bondi (closed circle), Fraser (open square) and Russet Burbank (shaded open triangle) potato crops grown between $201 \mathrm{I}$ and 2012. Bars represent the standard error above and below the mean values. 
There is some indication that the tuber length depended on the stolon length to which they were attached. Bondi grew its longest tubers on a stolon of $\sim 20 \mathrm{~mm}$ of length, whereas Fraser and Russet Burbank grew them on stolons of $\sim 50$ and $40 \mathrm{~mm}$, respectively.

\section{DISCUSSION}

Bondi yield was 25\% higher than Fraser. These tuber yields were built on radiation interception, RUE, and partitioning. The lower tuber yield capacity for Fraser was associated with its low RUE. This is in accordance with previous findings of contrasting tuber yield potentials among different potato cultivars (Tekalign and Hammes, 2005a, 2005b).

Bondi had the widest grade yield distribution at final harvest (Fig. 2) and the highest average tuber weight. The link between the average tuber size and the spread of distribution has previously been reported (Struik et al., 1991; Searle, 1999). If we define tuber sink strength as the ability of sink organs (or a net C user [Dwelle, 1990]) to accumulate C compounds (Marcelis, 1996), then it is plausible that there is corresponding increase in tuber yield, average tuber weight and tuber sink strength in the present work. This suggests these are inter-related traits (Marcelis, 1996).

Tuber growth rate was higher for Bondi compared with Fraser and Russet Burbank. This attribute influences tuber size distribution (Struik et al., 1990; Struik et al., 1991). It is possible that the tuber bulking in Bondi compensated in a way for the lower plant tuber number (Lynch and Tai, 1989). This implies that the tuber sink strength was related to total tuber biomass accumulation (Engels and Marschner, 1986) rather than the number of tubers, as suggested by Sale (1973). Similar results have been described by Marcelis (1993) for cucumbers (Cucumis sativus L.). The implication is that the total sink is the product of tuber number and potential tuber size. Cultivars

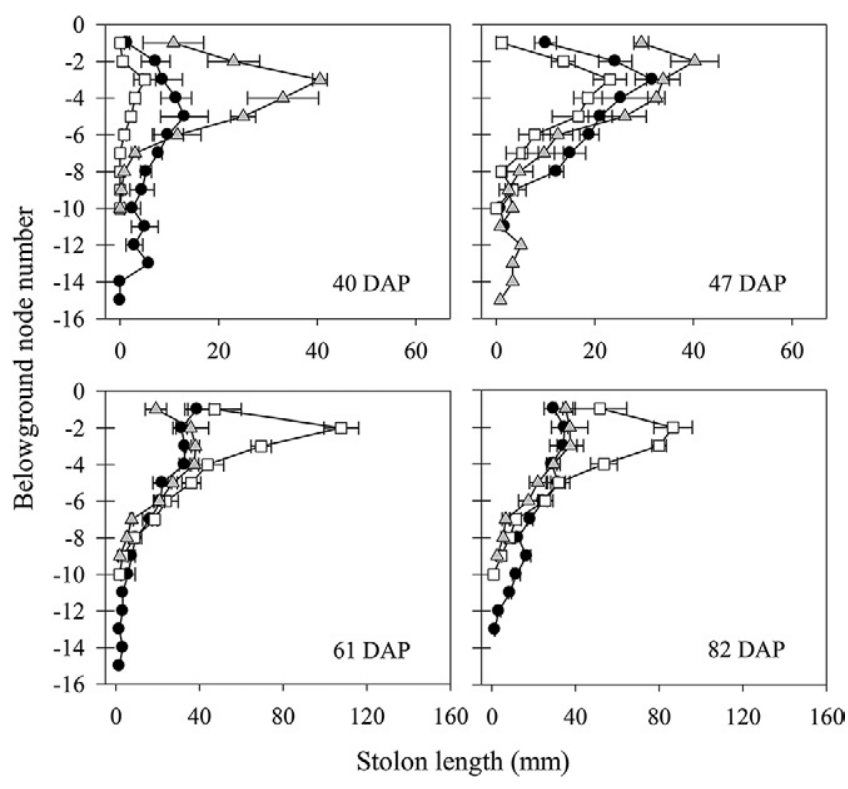

Fig. 8. Average length $(\mathrm{mm})$ of primary stolons at different node positions (number) on the belowground main stem of Bondi (closed circle), Fraser (open square) and Russet Burbank (shaded open triangle) potato crops measured from November 2011 (40 d after planting; DAP) to January 2012 (82 DAP). Bars represent the standard error above and below the mean values. with a higher total sink strength are then expected to have the highest yield.

For all crops $R_{\text {cum }}$ did not affect yield and the spatial and temporal pattern of canopy development was similar (Fig. 3). Specifically at the time of $95 \%$ final tuber DM all crops had accumulated the same amount of total radiation $\left(\sim 1650 \mathrm{MJ} \mathrm{m}^{-2}\right)$.

Early crop emergence of Russet Burbank did not lead to the early establishment of the canopy as found by Fandika (2012). In all crops, maximum ground cover was reached after $\sim 500^{\circ} \mathrm{Cd}(\sim 73 \mathrm{DAP})$. This is in agreement with Spitters (1990) who found little difference among treatments and cultivars as to when maximum canopy ground cover was achieved.

The higher yield of Bondi can be attributed to its high RUE (Fig. 4). This trait was likely to be associated with the highest total tuber sink strength in this cultivar. A positive association between organ sink size (analogous to sink strength), photosynthesis, and RUE has been shown for wheat (Triticum aestivum L.) (Blum et al., 1988) and sunflower (Helianthus annuus L.) (Sadras et al., 1991). Similar source-sink interactions have also been suggested for potato (Schapendonk et al., 1995; Tekalign and Hammes, 2005a).

Bondi RUE averaged $1.24 \mathrm{~g} \mathrm{DM} \mathrm{MJ}^{-1}$ total intercepted radiation which was $20 \%$ higher than for Fraser and $~ 12 \%$ higher than Russet Burbank. The RUE values found in the present study are within the range reported by Manrique et al. (1991) in different parts of the world ( 0.72 and $1.76 \mathrm{~g}$ total $\mathrm{DM} \mathrm{MJ}^{-1}$ of total solar radiation), but are lower than those exceeding $2 \mathrm{~g}$ total $\mathrm{DM} \mathrm{MJ}^{-1}$ total solar radiation reported for the Tunisian winter by Kooman et al. (1996a).

For a fixed amount of radiation intercepted, RUE can be equated to the rate of gross photosynthesis minus growth respiration (expressed as an efficiency whose value differs depending

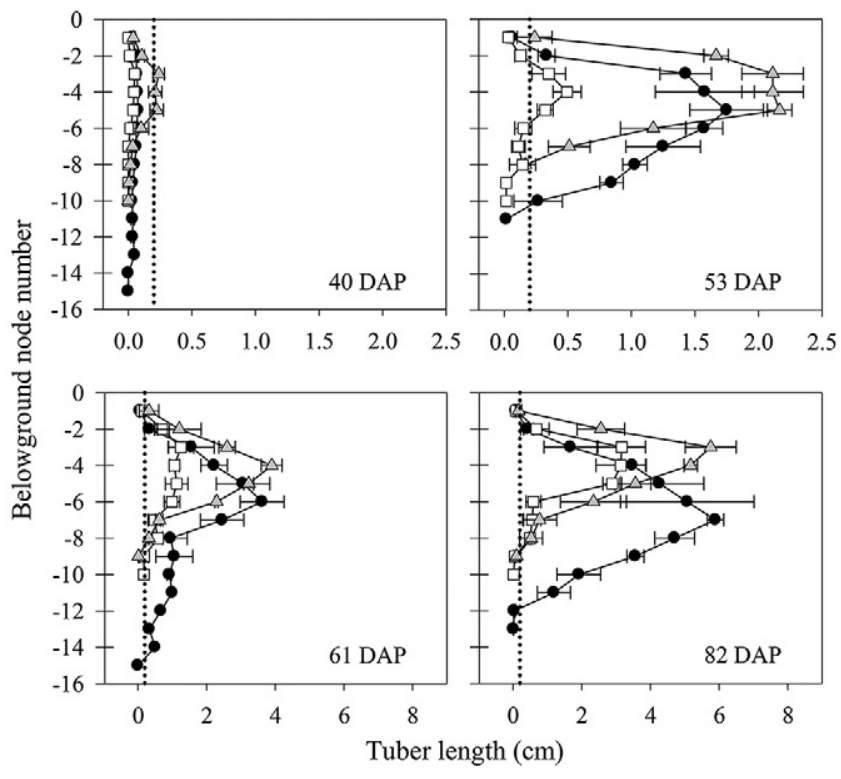

Fig. 9. Mean length $(\mathrm{mm})$ of tubers grown from a primary stolon at different node position (number) on the belowground main stem of Bondi (closed circle), Fraser (open square) and Russet Burbank (shaded open triangle) potato crops measured from November $201 \mathrm{ll}$ (40 d after planting; DAP) to January 2012 (82 $\mathrm{DAP})$. Vertical dotted lines indicate tuber initiation ( $\mathrm{TI})$ when the tip of the primary stolon had reached $2 \mathrm{~mm}$. Bars represent the standard error above and below the mean values. 
on the composition of the biomass being synthesized), and maintenance respiration which consumes photosynthate at a rate that depends on temperature and the amount of existing biomass that is being maintained (Hay and Porter, 2006). The result of this is commonly reported as rate of leaf net photosynthesis. Tekalign and Hammes (2005a), for example, have found different rates of leaf net photosynthesis among different determinate potato cultivars. However, Van Der Zaag and Doornbos (1987) suggested that differences among cultivars in their efficiency to utilize light arise mainly from differences in the rate of photosynthesis, particularly when grown under stress conditions. High temperature (Ku et al., 1977; Timlin et al., 2006), water stress (Van Der Zaag and Doornbos, 1987; Trebejo and Midmore, 1990), non optimum levels of N (Van Der Zaag and Doornbos, 1987; Vos and van der Putten, 1998; Searle, 1999; Shah et al., 2004) and pathogens (Van Oijen, 1991; Shah et al., 2004) have all been linked to low RUE values in potato crops.

However, none of these agronomic factors were present in this study. Thus, it seems likely the RUE difference among these cultivars were physiological rather than agronomic. For example, lower total and individual tuber sink strength for Fraser was shown by its lower LGR. Previous reports have shown a strong correlation between DM yield and net photosynthesis for a range of potato cultivars (Tekalign and Hammes, 2005a). In addition, the progressive increase in leaf DM (Fig. 6) for Fraser may have caused photosynthesis downregulation in the leaves, thus contributing to a decrease in net photosynthetic rate. Dickinson et al. (1991), for example, associated the excess of $\mathrm{C}$ in source leaves of tomato (Lycopersicon esculentum Mill.) plants with a block in sucrose translocation. Local sucrose accumulation slows photosynthesis by creating a feed-back limitation of the chloroplast activity when photosynthates are unable to be remobilized from the leaf (Dickinson et al., 1991; Jeuffroy and Ney, 1997; Pessarakli, 2005). It was shown that Fraser maintained a lower SLA (thicker leaves) for most of the period of tuber bulking (Fig. 7). Leaves with low SLA and long life span have lower assimilation rates per unit mass (Reich et al., 1997). These thicker leaves (i.e., lower SLA) may reduce the net $\mathrm{C}$ fixation on a leaf mass basis from shaded chloroplasts in the lower parts of the leaf lamella. A second possibility is that an increase in non-structural carbohydrates in some species both decreases SLA and limits C fixation (Meziane and Shipley, 2001). On the other hand, the earlier tuber initiation (Fig. 9) and bulking in Russet Burbank may have led to premature competition for resources thus compromising radiation capacity in this cultivar. Allen and Scott (1980), for example, reported that earliness in potato is accompanied by a lower tuber yield.

The high partitioning rate (Fig. 1 and 5) led Bondi to a higher final tuber yield. It was also shown that around the time of $95 \%$ final tuber yield (after all crops had begun to senesce), Bondi had a higher HI $(0.82 \pm 0.01)$ than Fraser $(0.74 \pm 0.02)$. Previously, Tekalign and Hammes (2005b) found potato cultivar differences in terms of DM allocation to the different plant organs. They also attributed the low tuber dry mass in some cultivars to the poor capacity of DM allocation by this organ.

The higher total tuber sink strength in Bondi compared with Fraser explained the higher tuber DM demand, hence, higher
DM partitioning to tubers in Bondi. The high demand was shown by the time of tuber initiation (Fig. 9) being delayed in Fraser compared with the other cultivars. The LGR was 25\% lower in Fraser than Bondi. According to Engels and Marschner (1986) the tuber sink strength in the initial growth phase is determined by the weight of the tubers, as a result of their time of initiation, initial weight and relative growth rate.

It appears that factors which influence "strength" of the tuber sink affect both assimilate allocation and the leaf longevity in potato plants (Kooman and Rabbinge, 1996). In the present study this was illustrated for Fraser. First, its low total and individual tuber sink demand appears to have caused photosynthate to accumulate in the canopy leaves. It was shown that Fraser had a low SLA during the tuber growth phase (Fig. 7) and maintained a high DM concentration in its leaves later in the growth season ( $79 \%$ of the total aboveground biomass; Fig. 6). If carbon is partitioned into starch in the leaf rather than sucrose it becomes readily unavailable for export from the leaf tissue (Dwelle, 1990) and accumulates in the leaf. This culminates in longer canopy duration, as seen for Fraser, from a low canopy senescence rate (Fig. 3). This result resembles a non-functioning "stay green" (or cosmetic stay green) trait in maize crops with low HI (Kosgey et al., 2013). According to Hörtensteiner (2009), the maintenance of chlorophyll concentration could lead to a reactive oxygen species (ROS) production and cause chlorophyll-mediated photo-destruction. The author suggested that for stay-green individuals this oxidative stress could result in a yield reduction. However, functioning stay-green has been associated to an extension of photosynthetic activity, leading to higher potato yields in drought tolerant genotypes grown under water restriction (Ramírez et al., 2014; Rolando et al., 2015). Further studies could examine the association among tuber sink strength, starch concentration in the leaf and photosynthesis rate under controlled and restricted water conditions.

Unlike seed crops (Feller and Keist, 1986) remobilization from senescing leaves is not central for the nutrient budget in potato crops. Bondi decreased leaf DM after reaching a maximum value ( 100 DAP) while Fraser showed no signs of leaf DM depletion (Fig. 6). Nevertheless, this leaf DM remobilization in Bondi represented only $0.8 \mathrm{t} \mathrm{ha}^{-1}$ and, thus represented only $20 \%$ of the $3.5 \mathrm{tha}^{-1}$ yield difference.

The longer stolons in Fraser appear to be associated with lower sink strength, and appear to have reduced tuber initiation and growth (Fig. 8 and 9). These stolons $(\sim 50 \mathrm{~mm})$ were the site of the larger tubers produced in this cultivar compared with Bondi ( $20 \mathrm{~mm}$; Fig. 8 and 9). Therefore, it seems that the production of longer stolons restrained the development of the individual tuber sink strength in Fraser possibly by increasing transport resistance to photosynthates. Similar conclusions were stated by Engels and Marschner (1986) who found a significant correlation between the growth rate of tubers and the volume and cross-sectional area of the phloem. The final size of the stolon has been reported as a consistent genetic trait (Kratzke and Palta, 1992) and crucial for tuber size distribution (Struik et al., 1991). Thus short stolons could be included as selection criteria for the production of larger tubers in potato breeding, or conversely long stolons for smaller tubers to meet a specialist market. 
The longer stolons in Fraser may have resulted from a short critical photoperiod (i.e., photoperiod that still permits tuber initiation) trait. This is because in favorable conditions stolon elongation will continue until the time of onset of tuber induction (Brown, 2007). Previous work has shown that long days (or photoperiod; e.g., potato growing season in Canterbury) increases stolon length (Abd El-Hak, 1969) and reduces the induction of tuber initiation (Kooman et al., 1996b). Wheeler and Tibbitts (1997), for example, conducted a growth room experiment with potatoes exposed to different photoperiod regimes. They suggested that higher yields could be achieved by short daylengths during early plant growth; to promote early tuber initiation, followed by high daily photosynthetic photon flux from long days later (at crop maturity) to sustain tuber growth.

Figures 8 and 9 indicate that the sink demand operated within a certain pattern associated with the node position on the belowground main stems, stolon elongation, and tuber initiation. Vreugdenhil and Struik (1989), for example, showed that the earlier formed stolons required a longer period to initiate a tuber compared with the later formed ones. In the present work, the larger tubers were produced in the middle nodes in the belowground main stem profile. This is in agreement with Cother and Cullis (1985). They found that the top and bottom nodes on the belowground main stems were the least likely to bear a marketable tuber (heavier than $45 \mathrm{~g}$ ). It is possible that the lower nodes on the belowground main stems barely initiate and grow tubers because of their distance from the source. Moreover, tuber growth in the upper node positions (near the soil surface) might be restrained by lower soil moisture and possibly light exposure (Kumar and Wareing, 1972). It was observed that on many occasions the two uppermost nodes (on the belowground main stem) initiated a leaf on the tip of the stolons rather than tubers. Future work could focus on modeling stolon length on the middle nodes in the belowground stems and final tuber yield and distribution.

\section{CONCLUSIONS}

Cultivar tuber yield differences were not determined by $R_{\text {cum }}$ differences at the end of the season. The tuber sink strength seemed to be causally related to tuber yields. Bondi created the highest tuber sink strength (demand) and maintained the highest RUE (supply). These two traits are probably interrelated. Fraser had the highest $R_{\text {cum }}$ at the time of haulm desiccation, but its yield was constrained by the low tuber sink strength and a low RUE maintenance.

The higher sink strength in Bondi was attributed to fewer larger tubers produced in the middle positioned nodes on the belowground main stems. The early tuber initiation in Russet Burbank may have been detrimental to the performance of this crop. The production of longer stolons restrained the development of the tuber sink strength in Fraser possibly by increasing sink resistance to photosynthates. This downregulation seems to be linked to the stay-green leaf trait observed in this cultivar.

\section{ACKNOWLEDGMENTS}

The authors gratefully acknowledge financial support of The New Zealand Institute for Plant \& Food Research limited, Potatoes New Zealand, and Lincoln University, New Zealand. The authors also thank three anonymous reviewers for helpful comments and suggestions.

\section{APPENDIX A}

\section{Daily Temperature Variation}

Figure A1 shows daily minimum, maximum, and average air temperatures between planting and harvesting.

\section{APPENDIX B}

\section{Planting Preparation and Management Practices}

On 10 Aug. 2011 the areas were plowed and on 6 Oct. 2011 $250 \mathrm{~kg} \mathrm{ha}^{-1}$ of "Cropmaster" 15 (15-10-10-8 N-P-K-S) was surface applied. The site was then rolled and power harrowed. The day before planting, two-row beds were mechanically formed and the soil "conditioned" by removing clods to a narrow channel. A moldboard plow was used to create a trench with $0.3 \mathrm{~m}$ of depth in each row. An insecticide Imicacloprid

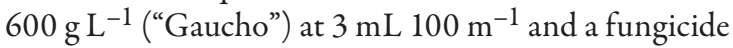

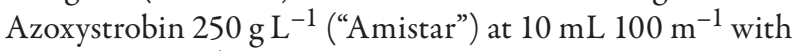
$150 \mathrm{~L}_{\text {water }} \mathrm{ha}^{-1}$ was applied on the rows. Fungicide and insecticide applications at the same rate were applied to the crop another 11 and 4 times, respectively, throughout the growth season.

\section{Weed Control}

On 28 Oct. 2011 pre-emergent herbicides metribuzin [4-amino-6-tert-butyl-3-methylsulfany-1,2,4-triazin-5-one] (Sencor) at $500 \mathrm{~g} \mathrm{ha}^{-1}$ and cyanazine [2-chloro-4(1-cyano1-methylethylamino)-6-ethylamino-s-triazine] (Bruno) $2 \mathrm{~L} \mathrm{~g} \mathrm{ha}^{-1}$ with $400 \mathrm{~L}$ of water were applied for weed control. From 15 Jan. 2012 any weeds emerged in the plots were removed by hand.

\section{Fertilizer Applications}

Side-dressings of $\mathrm{N}$ fertilizer (urea, $46 \% \mathrm{~N}$ ) were applied based on soil test analyses (Table A1), using a hand spinner on 13 and 21 Dec. (100 $\mathrm{kg} \mathrm{N} \mathrm{ha}^{-1}$ each time), and 6 Jan. 2012 $\left(50 \mathrm{~kg} \mathrm{~N} \mathrm{ha}^{-1}\right)$. This was based on a potential potato yield of $20 \mathrm{t} \mathrm{DM} \mathrm{ha}^{-1}, 2 \%$ potato $\mathrm{N}$ content, and $100 \mathrm{~kg} \mathrm{ha}^{-1}$ of $\mathrm{N}$ required by the plant.

\section{Irrigation}

To provide an optimum level of water supply the experiment was irrigated eight times from 21 Dec. 2011 to 2 Feb. 2012 at a 5 to $8 \mathrm{~d}$ interval with a total of $30 \mathrm{~mm}$ on each application,

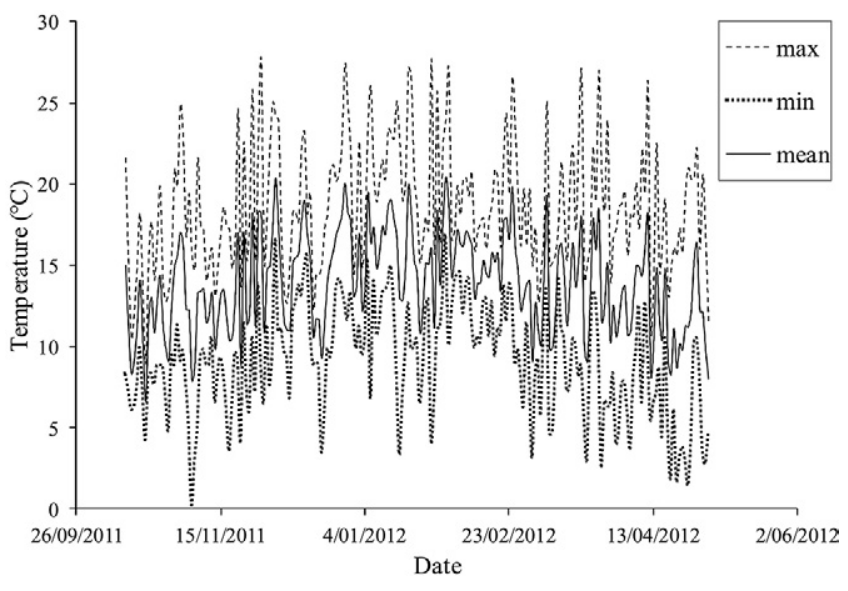

Fig. Al. Average daily maximum, minimum and average temperature measured between planting (I3 Oct. 20II) and crop harvest (2 May 20I2). 
Table AI. Soil test results for the Experimental site in Lincoln, Canterbury, NZ, from 20II. Soils tests were performed using Ministry of Agriculture and Fisheries Quick Test (MAF QT) procedures.†

\begin{tabular}{|c|c|c|c|c|c|c|c|}
\hline Nutrient & $\mathrm{pH}$ & $\mathrm{N}$ & P Olsen phosphate & $\mathrm{K}$ & $\mathrm{Ca}$ & $\mathrm{Mg}$ & $\mathrm{Na}$ \\
\hline & & $\mathrm{kg} \mathrm{ha}^{-\mathrm{I}}$ & $\mathrm{mg} \mathrm{L}^{-1}$ & 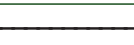 & - me 0.1 & & \\
\hline Soil test & 5.8 & 62 & 39 & 0.7 & 7.94 & 1.94 & 0.12 \\
\hline Optimum range & $5.4-5.8$ & & $30-60$ & $0.50-1.0$ & $4.0-10$ & $1.0-3.0$ & $0.0-0.50$ \\
\hline
\end{tabular}

† Soils tests were carried out using the Ministry of Agriculture and Fisheries Quick test (MAF QT). Nitrogen value represents mineralized $\mathrm{N}$ available in the soil. me = milliequivalents.

Table A2. Grade and total tuber fresh weight yields of Bondi, Fraser, and Russet Burbank potato crops grown from October to May 20II-20I2 at Canterbury, NZ.†

\begin{tabular}{|c|c|c|c|c|c|c|c|c|c|c|c|c|c|c|}
\hline \multirow[b]{3}{*}{ Cultivar } & \multicolumn{4}{|c|}{ Seed grade } & \multirow{2}{*}{\multicolumn{2}{|c|}{$\begin{array}{l}\text { Table grade } \\
113-170 \mathrm{~g}\end{array}$}} & \multicolumn{6}{|c|}{ Process grade (premium) } & \multirow{2}{*}{\multicolumn{2}{|c|}{ Total potato }} \\
\hline & \multicolumn{2}{|c|}{$0-50 \mathrm{~g}$} & \multicolumn{2}{|c|}{$50-113 \mathrm{~g}$} & & & \multicolumn{2}{|c|}{$170-250 \mathrm{~g}$} & \multicolumn{2}{|c|}{$250-350 \mathrm{~g}$} & \multicolumn{2}{|c|}{$>350 \mathrm{~g}$} & & \\
\hline & Yield & No. & Yield & No. & Yield & No. & Yield & No. & Yield & No. & Yield & No. & Yield & No. \\
\hline & $\mathrm{tha}^{-1}$ & $\mathrm{~m}^{-2}$ & $\mathrm{tha}^{-\mathrm{I}}$ & $\mathrm{m}^{-2}$ & $\mathrm{tha}^{-\mathrm{I}}$ & $m^{-2}$ & $\mathrm{tha}^{-\mathrm{I}}$ & $\mathrm{m}^{-2}$ & $\mathrm{tha}^{-\mathrm{I}}$ & $m^{-2}$ & $\mathrm{tha}^{-1}$ & $\mathrm{~m}^{-2}$ & $\mathrm{tha}^{-\mathrm{I}}$ & $\mathrm{m}^{-2}$ \\
\hline Bondi & 0.90 & 2.70 & 3.30 & 4.10 & 4.10 & 2.9 & 11.8 & 5.60 & 20.0 & 6.70 & 26.0 & 5.8 & 66.1 & 27.8 \\
\hline Fraser & 3.40 & 11.1 & 12.3 & 15.6 & 16.2 & 11.6 & 13.8 & 6.90 & 5.00 & 1.70 & 0.6 & 0.20 & 51.3 & 47.2 \\
\hline Russet Burbank & 2.40 & 7.10 & 14.2 & 17.6 & 13.9 & 10.0 & 13.0 & 6.50 & 5.50 & 1.90 & 3.10 & 0.70 & 52.0 & 43.7 \\
\hline$P$ & 0.003 & 0.002 & $<0.001$ & $<0.001$ & $<0.001$ & $<0.001$ & ns & ns & 0.002 & 0.003 & 0.003 & 0.002 & 0.067 & 0.006 \\
\hline LSD & 0.85 & 2.62 & 1.96 & 2.40 & 3.08 & 2.11 & 3.25 & 1.56 & 5.33 & 1.86 & 9.5 & 1.93 & 13.6 & 8.2 \\
\hline \multicolumn{15}{|c|}{ French fry } \\
\hline \multirow{3}{*}{ Cultivar } & \multicolumn{2}{|c|}{$(>113 \mathrm{~g})$} & & & & & & & & & & & & \\
\hline & Yield & No. & & & & & & & & & & & & \\
\hline & $\mathrm{tha}^{-1}$ & $\mathrm{~m}^{-2}$ & & & & & & & & & & & & \\
\hline Bondi & 61.9 & 21.0 & & & & & & & & & & & & \\
\hline Russet Burbank & 35.4 & 19.0 & & & & & & & & & & & & \\
\hline$P$ & 0.02 & 0.05 & & & & & & & & & & & & \\
\hline LSD & 15.01 & 1.88 & & & & & & & & & & & & \\
\hline
\end{tabular}

$\dagger$ No., number of potatoes; LSD = least significant difference. The comparison of tuber yield and numbers in the French fry grade does not include Fraser which is grown for crisp potato.

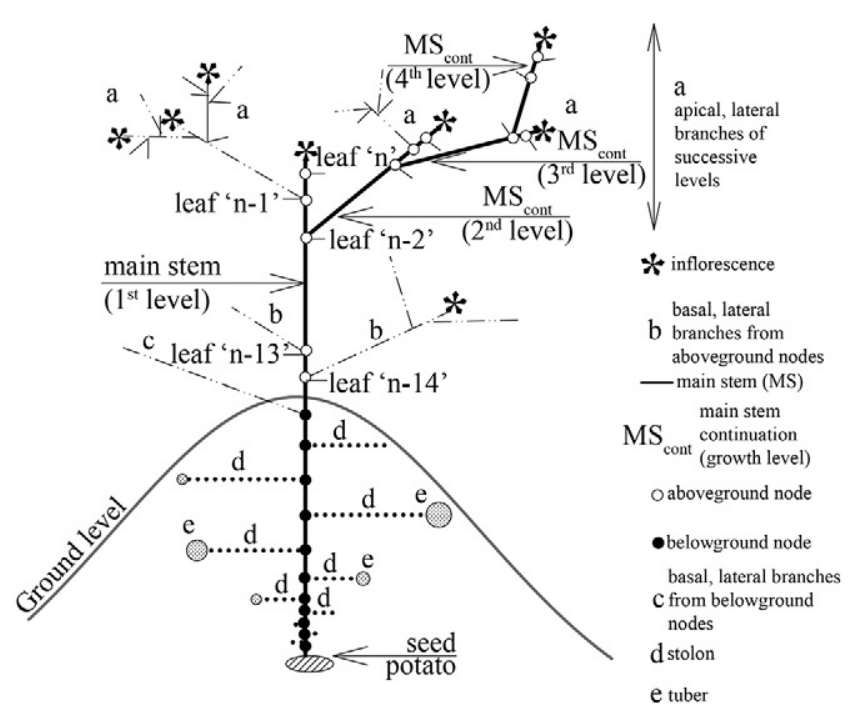

Fig. A2. Simplified diagram of one main stem produced by the seed potato with all its different organs (stolons, tubers, branches, leaves, and flowers), but excluding roots. Revised after Vos (1995) and Struik and Ewing (1995).

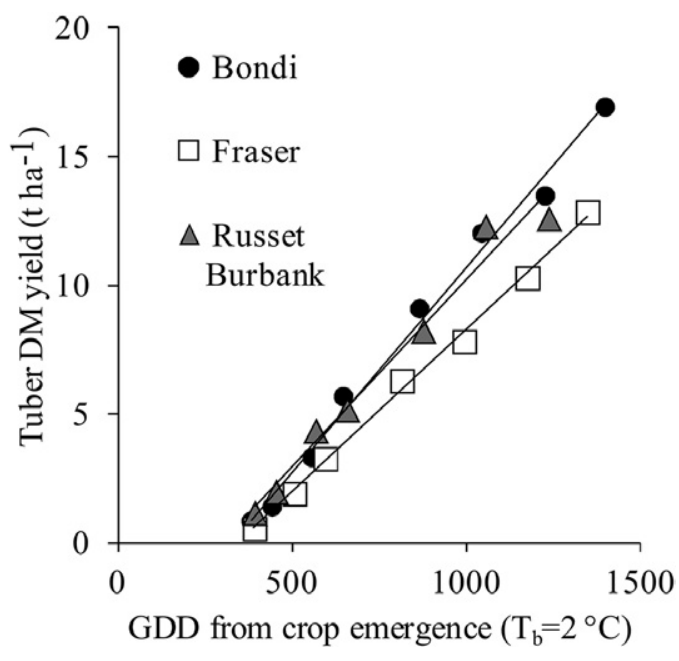

Fig. A3. Accumulated total dry matter (DM) against growing degree days (GDD) for Bondi, Fraser, and Russet Burbank potato crops planted on 14 Oct. 20II. A regression line was fitted to the accumulated total DM against GDD using all data-points within the range of 5 and $95 \%$ of the maximum yield for each cultivar: Bondi: $y=1.58 \times 10^{-2} x-517, R^{2}=0.99$; Fraser: $y=1.26 \times 10^{-2} x-435$, $R^{2}=0.99 ;$ Russet Burbank: $y=1.44 \times 10^{-2} x-425, R^{2}=0.98$. 
using a linear irrigator. The amount applied was based on the average daily potential evapotranspiration $\left(E_{p o}\right)$ of $4.0 \mathrm{~mm} \mathrm{~d}^{-1}$ (averaged from October to May) calculated from a long-term data series from 1960 to 2012.

In addition the irrigation was timed to prevent the actual soil moisture deficit from exceeding $60 \mathrm{~mm}$ in the top $400 \mathrm{~mm}$ of soil. The water stress threshold of $60 \mathrm{~mm}$ was calculated based on field capacity of about 30\% (Yunusa et al., 1995), $400 \mathrm{~mm}$ of root depth and $50 \%$ of soil water capacity available to the plant.

\section{APPENDIX C}

\section{Schematic Illustration of the Potato Plant}

A schematic diagram detailing only one main stem (grown from the seed potato) with its different organs (stolons, tubers, branches, leaves, and flowers) is shown in Fig. A2.

\section{APPENDIX D}

\section{Normalized Difference Vegetation Index Calculations}

NDVI was calculated according to Eq. [B1]:

$$
\mathrm{NDVI}=(\mathrm{NIR}-\mathrm{VIS}) /(\mathrm{NIR}+\mathrm{VIS})
$$

The NIR and VIS wavelengths measured from the instrument and used to calculate the NDVI were 760 and $660 \mathrm{~nm}$, respectively. All reflectance measurements were obtained between 1000 and $1500 \mathrm{~h}$, based on local time during clear sky conditions. The potato canopy area for each assessment covered a circle $0.8 \mathrm{~m}$ in diameter. The NDVI reading were done with the CropScan sensors attached to a probe placed between the two rows of each plot. A bare soil reading was taken on the day of each measurement. There was a need to transform the NDVI reading to estimate the maximum cover and correct the values for bare soil reflectance. This is because bare soil readings ranged from 0.09 to 0.11 NDVI which overestimated canopy cover during the early phase of canopy expansion (right after crop emergence). Moreover, from visual assessments it

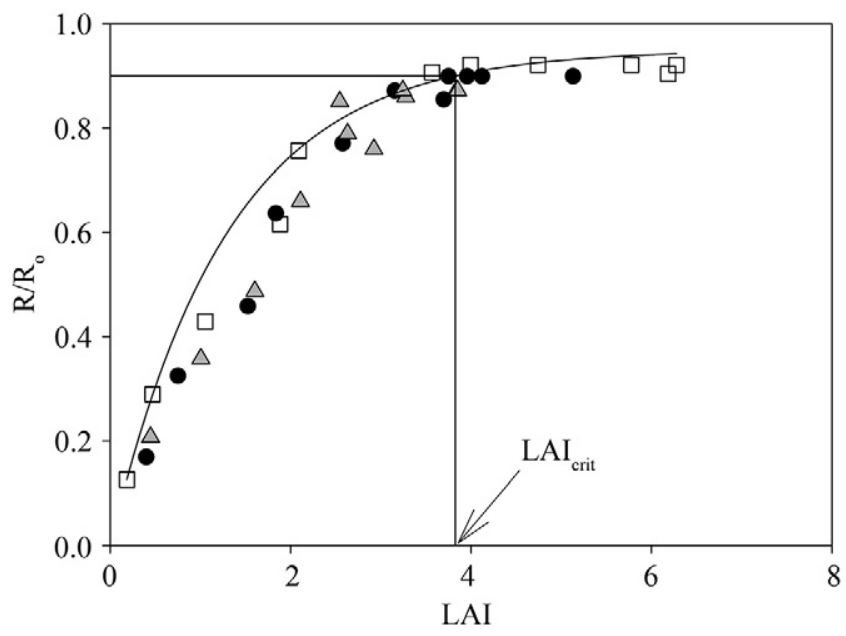

Fig. A4. Radiation interception $\left(R / R_{\circ}\right)$ against leaf area index (LAI) for Bondi (closed circle), Fraser (open square) and Russet Burbank (shaded open triangle) potato crops from 23 Nov. 20II to $29 \mathrm{Feb}$. 2012. Regression $R / R_{0}=0.95$ [I- $\left.\exp (-0.77 x \mathrm{LAI})\right]$, $R^{2}=0.97$. Slope standard error $=0.02$. was noticed that the maximum canopy ground cover readings underestimated the maximum cover achieved by the canopy $\left(R / R_{\mathrm{o}}=0.95\right)$. Therefore, $R / R_{\mathrm{o}}$ was corrected for each plot using the NDVI values calibrated according to Eq. [B2]; based on Carlson and Ripley (1997):

$$
\begin{aligned}
R / R_{\mathrm{o}}= & \left(\mathrm{NDVI}_{\mathrm{r}}-\mathrm{NDVI}_{\mathrm{s}}\right) /\left(\mathrm{NDVI}_{\max }-\mathrm{NDVI}_{\mathrm{s}}\right) \\
& \times C
\end{aligned}
$$

where $\mathrm{NDVI}_{r}$ is the Index measured on the crop, NDVI is the Index measurement on a bare soil, $C_{\max }$ is the actual maximum crop canopy cover and NDVI $I_{\max }$ is the highest NDVI reading for the plot throughout the season. $C_{\max }$ was considered 0.95 for the calculations. It follows that, when NDVI ${ }_{r}$ equalled $\mathrm{NDVI}_{s}$ the NDVI values were fully from the bare soil (no canopy), thus $R / R_{\mathrm{o}}$ equalled zero. However, when the plot reached maximum canopy reading $\left(\mathrm{NDVI}_{\max }\right), R / R_{\mathrm{o}}$ equalled 0.95 .

\section{APPENDIX E Linear Growth Rate}

Linear growth rate was calculated by fitting a linear regression between accumulated tuber DM against GDD using all data-points within the range of 5 and $95 \%$ of the maximum yield for each cultivar is depicted in Fig. A3.

\section{APPENDIX F}

\section{Marketable Tuber Yield and Number}

Grade FM yield, total FM tuber yield and number differences among Bondi, Fraser, and Russet Burbank are shown in Table A2.

\section{APPENDIX G}

\section{Leaf Area Index and Extinction Coefficient}

Figure A4 shows the regression fitted between leaf area index (LAI) and the fraction of radiation interception $\left(R / R_{\mathrm{o}}\right)$ for a coefficient $(k)$ of 0.77 .

\section{REFERENCES}

Abd El-Hak, M.Z. 1969. Influence of different daylengths on development and tuber formation of the potato plant. 281st Communication. Mededelingen Landbouwhogeschool, Wageningen, the Netherlands. Deel 69. No. 18. http://edepot.wur.nl/291208 (accessed on 18 Apr. 2016).p. 1-16.

Allen, E.J., and R.K. Scott. 1980. An analysis of growth of the potato crop. J. Agric. Sci. 94:583-606. doi:10.1017/ S0021859600028598

Blum, A., J. Mayer, and G. Golan. 1988. The effect of grain number (sink size) on source activity and its water-relations in wheat. J. Exp. Bot. 39:106-114. doi:10.1093/jxb/39.1.106

Brown, H.E. 2004. Understanding the yield and water use of dryland forage crops in New Zealand. Ph.D. thesis. Lincoln Univ., Christchurch, NZ.. https://researcharchive.lincoln.ac.nz/ handle/10182/1697 (accessed 15 Sept. 2015).

Brown, P.H. 2007. The canon of potato science: 37. Stolonization, tuber induction and tuberization. Potato Res. 50:363-365 doi:10.1007/s11540-008-9070-9.

Carlson, T.N., and D.A. Ripley. 1997. On the relation between NDVI, fractional vegetation cover, and leaf area index. Remote Sens. Environ. 62:241-252. doi:10.1016/ S0034-4257(97)00104-1 
Cother, E.J., and B.R. Cullis. 1985. Tuber size distribution in cv. Sebago and quantitative effects of Rhizoctonia solani on yield. Potato Res. 28:1-14. doi:10.1007/BF02357565

Dickinson, C.D., T. Altabella, and M.J. Chrispeels. 1991. Slowgrowth phenotype of transgenic tomato expressing apoplastic invertase. Plant Physiol. 95:420-425. doi:10.1104/pp.95.2.420

Dwelle, R.B. 1990. Source/sink relationships during tuber growth. Am. Potato J. 67:829-833 doi:10.1007/BF03044295.

Ellissèche, D., and J. Hoogerndoorn. 1995. The use of models in potato breeding. In: A.J. Haverkort and D.K.L. Mackerron, editors, Potato ecology and modelling of crops under conditions limiting growth. Kluwer Academic Publishers, Dordrecht, the Netherlands. p. 341-356. doi:10.1007/978-94-011-0051-9_22

Engels, C., and H. Marschner. 1986. Allocation of photosynthate to individual tubers of Solanum tuberosum L.: III. Relationship between growth rate of individual tubers, tuber weight and stolon growth prior to tuber initiation. J. Exp. Bot. 37:1813-1822 doi:10.1093/jxb/37.12.1813.

Fandika, I.R. 2012. Comparison of heritage and modern crop cultivars in response to irrigation and nitrogen management, Ph.D. thesis. Massey Univ., Palmerston North, NZ. http://mro. massey.ac.nz/handle/10179/4191 (accessed 15 Sept. 2015).

Feller, U., and M. Keist. 1986. Senescence and nitrogen metabolism in annual plants. In: H. Lambers, J.J. Neeteson, and I. Stulen, editors, Fundamental, ecological and agricultural aspects of nitrogen metabolism in higher plants. Springer Netherlands, Haren, the Netherlands. p. 219-234. doi:10.1007/978-94-009-4356-8_34

Gamon, J.A., C.B. Field, M. Goulden, K. Griffin, A. Hartley, G. Joel et al. 1995. Relationships between NDVI, canopy structure, and photosynthetic activity in three Californian vegetation types. Ecol. Appl. 5:28-41. doi:10.2307/1942049

Griffin, T.S., B.S. Johnson, and J.T. Ritchie. 1993. A simulation model for potato growth and development: SUBSTOR-POTATO Version 2.0. Dep. of Agron. and Soil Sci., College of Tropical Agric. and Human Resources, Univ. of Hawaii, Honolulu.

Hay, R.K.M., and J.R. Porter. 2006. The physiology of crop yield. Blackwell Publ., Oxford, UK.

Hörtensteiner, S. 2009. Stay-green regulates chlorophyll and chlorophyll-binding protein degradation during senescence. Trends Plant Sci. 14:155-162. doi:10.1016/j.tplants.2009.01.002

Jamieson, P.D., P.J. Stone, R.F. Zyskowski, S. Sinton, and R.J. Martin. 2004. Implementation and testing of the Potato Calculator, a decision support system for nitrogen and irrigation management. In: D.K.L. Mackerron and A.J. Haverkort, editors, Decision support systems in potato production: Bringing models to practice. Wageningen Academic Publ., Wageningen, the Netherlands. p. 85-99.

Jefferies, R.A. 1993. Use of a simulation model to assess possible strategies of drought tolerance in potato (Solanum tuberosum L.). Agric. Syst. 41:93-104. doi:10.1016/0308-521X(93)90083-E

Jeuffroy, M.H., and B. Ney. 1997. Crop physiology and productivity. Field Crops Res. 53:3-16. doi:10.1016/S0378-4290(97)00019-1

Kooman, P.L., M. Fahem, P. Tegera, and A.J. Haverkort. 1996a. Effects of climate on different potato genotypes. 1. Radiation interception, total and tuber dry matter production. Eur. J. Agron. 5:193-205. doi:10.1016/S1161-0301(96)02031-X

Kooman, P.L., M. Fahem, P. Tegera, and A.J. Haverkort. 1996b. Effects of climate on different potato genotypes. 2. Dry matter allocation and duration of the growth cycle. Eur. J. Agron. 5:207-217. doi:10.1016/S1161-0301(96)02032-1

Kooman, P.L., and A.J. Haverkort. 1995. Modelling development and grow th of the potato crop influenced by temperature and daylength: LINTUL-POTATO. In: A.J. Haverkort., and D.K.L. Mackerron, editors, Potato ecology and modelling of crops under conditions limiting growth. Kluwer Academic Publ., Dordrecht, the Netherlands. p. 41-59.
Kooman, P.L., and R. Rabbinge. 1996. An analysis of the relationship between dry matter allocation to the tuber and earliness of a potato crop. Ann. Bot. (Lond.) 77:235-242. doi:10.1006/anbo.1996.0027

Kosgey, J.R., D.J. Moot, A.L. Fletcher, and B.A. McKenzie. 2013. Dry matter accumulation and post-silking $\mathrm{N}$ economy of 'staygreen' maize (Zea mays L.) hybrids. Eur. J. Agron. 51:43-52 doi:10.1016/j.eja.2013.07.001.

Kratzke, M.G., and J.P. Palta. 1992. Variations in stolon length and in incidence of tuber roots among eight potato cultivars. Am. Potato J. 69:561-570. doi:10.1007/BF02852128

Ku, S.B., G.E. Edwards, and C.B. Tanner. 1977. Effects of light, carbon dioxide, and temperature on photosynthesis, oxygen inhibition of photosynthesis, and transpiration in Solanum tuberosum. Plant Physiol. 59:868-872. doi:10.1104/pp.59.5.868

Kumar, D., and P.F. Wareing. 1972. Factors controlling stolon development in the potato plant. New Phytol. 71:639-648. doi:10.1111/j.1469-8137.1972.tb01274.x

Lynch, D.R., and G.C.C. Tai. 1989. Yield and yield component response of eight potato genotypes to water stress. Crop Sci. 29:1207-1211. doi:10.2135/cropsci1989.0011183X002900050024x

Marcelis, L.F.M. 1996. Sink strength as a determinant of dry matter partitioning in the whole plant. J. Exp. Bot. 47:1281-1291. doi:10.1093/jxb/47.Special_Issue.1281

Marcelis, L.F.M. 1993. Fruit growth and biomass allocation to the fruits in cucumber. 1. Effect of fruit load and temperature. Sci. Hortic. (Amsterdam) 54:107-121. doi:10.1016/0304-4238(93)90059-Y

Manrique, L.A., J.R. Kiniry, T. Hodges, and D.S. Axness. 1991. Dry matter production and radiation interception of potato. Crop Sci. 31:10441049. doi:10.2135/cropsci1991.0011183X003100040040x

Meziane, D., and B. Shipley. 2001. Direct and indirect relationships between specific leaf area, leaf nitrogen and leaf gas exchange. Effects of irradiance and nutrient supply. Ann. Bot. (Lond.) 88:915-927. doi:10.1006/anbo.2001.1536

Monteith, J.L. 1977. Climate and the efficiency of crop production in Britain. Philos. Trans. R. Soc. Lond. B Biol. Sci. 281:277-294. doi:10.1098/rstb.1977.0140

Oliveira, J.S. 2015. Growth and development of potato (Solanum tuberosum L.) crops after different cool season storage. Ph.D. Lincoln Univ., Christchurch, NZ. https://researcharchive.lincoln.ac.nz/bitstream/handle/10182/6494/Oliveira_PhD_open. pdf? sequence $=4$ (accessed 15 Sept. 2015).

Oliveira, J.S., D.J. Moot, and H.E. Brown. 2014. Seed potato physiological age and crop establishment. Agron. Soc. N. Z. 44:85-93.

Pessarakli, M. 2005. Handbook of photosynthesis. CRC Press, Boca Raton, FL.

Ramírez, D., W. Yactayo, R. Gutiérrez, V. Mares, F. De Mendiburu, A. Posadas, and R. Quiroz. 2014. Chlorophyll concentration in leaves is an indicator of potato tuber yield in water-shortage conditions. Sci. Hortic. (Amsterdam) 168:202-209. doi:10.1016/j. scienta.2014.01.036

Rolando, J., D. Ramirez, W. Yactayo, P. Monneveux, and R. Quiroz. 2015. Leaf greenness as a drought tolerance related trait in potato (Solanum tuberosum L.). Environ. Exp. Bot. 110:27-35. doi:10.1016/j.envexpbot.2014.09.006

Reich, P.B., M.B. Walters, and D.S. Ellsworth. 1997. From tropics to tundra: Global convergence in plant functioning. Proc. Natl. Acad. Sci. USA 94:13730-13734. doi:10.1073/pnas.94.25.13730

Sadras, V.O., D.M. Whitfield, and D.J. Connor. 1991. Transpiration efficiency in crops of semi-dwarf and standard-height sunflower. Irrig. Sci. 12:87-91. doi:10.1007/BF00190015

Sale, P.J.M. 1973. Productivity of vegetable crops in a region of high solar imput. I. Growth and development of the potato (Solanum tuberosum L.). Aust. J. Agric. Res. 24:733-749. doi:10.1071/AR9730733 
Schapendonk, A.H.C.M., C.S. Pot, and J. Goudriaan. 1995. Simulated effects of elevated carbon dioxide concentration and temperature on the productivity of potato. In: A.J. Haverkort and D.K.L. MacKerron, editors, Potato ecology and modelling of crops under conditions limiting growth. Kluwer Academic Publishers, Dordrecht, the Netherlands. p. 101-113. doi:10.1007/978-94-011-0051-9_7

Schittenhelm, S., H. Sourell, and F.J. Lopmeier. 2006. Drought resistance of potato cultivars with contrasting canopy architecture. Eur. J. Agron. 24:193-202. doi:10.1016/j.eja.2005.05.004

Searle, B.P. 1999. Nitrogen and irrigation effects on yield and quality of potatoes (Solanum tuberosum L.), Ph.D. thesis. Lincoln Univ., Christchurch, NZ. p. 236. http://hdl.handle.net/10182/1873 (accessed 15 Sept. 2015).

Shah, S.F.A., B.A. McKenzie, R.E. Gaunt, J.W. Marshall, and C.M. Frampton. 2004. Effect of production environments on radiation interception and radiation use efficiency of potato (Solanum tuberosum) grown in Canterbury, New Zealand. N. Z. J. Crop Hortic. Sci. 32:113-119. doi:10.1080/01140671.2004.9514285

Spitters, C.J.T. 1990. Crop growth models: Their usefulness and limitations. Acta Hortic. 267:349-368. doi:10.17660/ ActaHortic.1990.267.42

Spitters, C.J.T., A.E.F. Neele, and A.H.C.M. Schapendonk. 1989. Crop physiological components of tuber yield and their use in potato breeding. In: K.M. Louwes, H.A.J.M. Toussaint, and L.M.W. Dellaert, compilers, Parental Line Breeding and Selection in Potato Breeding: Proceedings of the Joint Conference of the EAPR Breeding Section and EUCARPIA Potato Section, Wageningen, the Netherlands. 11-16 Dec. 1988. Pudoc, Wageningen, the Netherlands.

Struik, P.C., and E.E. Ewing. 1995. Crop physiology of potato (Solanum tuberosum): Responses to photoperiod and temperature relevant to crop modelling. In: A.J. Haverkort and D.J. MacKerron, editors, Potato ecology and modelling of crops under conditions limiting growth. Kluwer Academic Publ., Dordrecht, the Netherlands. p. 19-40. doi:10.1007/978-94-011-0051-9_2

Struik, P.C., A.J. Haverkort, D. Vreugdenhil, C.B. Bus, and R. Dankert. 1990. Manipulation of tuber-size distribution of a potato crop. Potato Res. 33:417-432. doi:10.1007/BF02358019

Struik, P.C., D. Vreugdenhil, A.J. Haverkort, C.B. Bus, and R. Dankert. 1991. Possible mechanisms of size hierarchy among tubers on one stem of a potato (Solanum tuberosum L.) plant. Potato Res. 34:187-203 doi:10.1007/BF02358041.

Tekalign, T., and P.S. Hammes. 2005a. Growth and productivity of potato as influenced by cultivar and reproductive growth. I. Stomatal conductance, rate of transpiration, net photosynthesis, and dry matter production and allocation. Sci. Hortic. (Amsterdam) 105:13-27 doi:10.1016/j.scienta.2005.01.029.
Tekalign, T., and P.S. Hammes. 2005b. Growth and productivity of potato as influenced by cultivar and reproductive growth. II. Growth analysis, tuber yield and quality. Sci. Hortic. (Amsterdam) 105:29-44 doi:10.1016/j.scienta.2005.01.021.

Timlin, D., S.M.L. Rahman, J. Baker, V.R. Reddy, D. Fleisher, and B. Quebedeaux. 2006. Whole plant photosynthesis, development, and carbon partitioning in potato as a function of temperature. Agron. J. 98:1195-1203 doi:10.2134/agronj2005.0260.

Trebejo, I., and D.J. Midmore. 1990. Effect of water stress on potato growth, yield and water use in a hot and a cool tropical climate. J. Agric. Sci. 114:321-334. doi:10.1017/S0021859600072713

Tucker, C.J. 1979. Red and photographic infrared linear combinations for monitoring vegetation. Remote Sens. Environ. 8:127-150 doi:10.1016/0034-4257(79)90013-0.

Van Der Zaag, D.E., and J.H. Doornbos. 1987. An attempt to explain differences in the yielding ability of potato cultivars based on differences in cumulative light interception, utilization efficiency of foliage and harvest index. Potato Res. 30:551-568 doi:10.1007/BF02367637.

Van Keulen, H., and W. Stol. 1995. Agro-ecological zonation for potato production. In: A.J. Haverkort and D.K.L. Mackerron, editors, Potato ecology and modelling of crops under conditions limiting growth. Kluwer Academic Publishers, Dordrecht, the Netherlands. p. 357-371. doi:10.1007/978-94-011-0051-9_23

Van Oijen, M. 1991. Light use efficiencies of potato cultivars with late blight (Phytophthora infestans). Potato Res. 34:123-132. doi:10.1007/BF02358033

Vos, J. 1995. Foliar development of the potato plant and modulations by environmental factors. In: P. Kabat, B. Marshall, B.J. Van Den Broek, J. Vos, and H. van Keulen, editors, Modelling and parameterization of the soil-plant-atmosphere system. Wageningen Pers, Wageningen, the Netherlands. p. 21-38.

Vos, J., and P.E.L. van der Putten. 1998. Effect of nitrogen supply on leaf growth, leaf nitrogen economy and photosynthetic capacity in potato. Field Crops Res. 59:63-72. doi:10.1016/ S0378-4290(98)00107-5

Vreugdenhil, D., and P.C. Struik. 1989. An integrated view of the hormonal regulation of tuber formation in potato (Solanum tuberosum). Potato Res. 75:525-531.

Wheeler, R.M., and T.W. Tibbitts. 1997. Influence of changes in daylength and carbon dioxide on the growth of potato. Ann. Bot. (Lond.) 79:529-533. doi:10.1006/anbo.1996.9999

Yunusa, I.A.M., D.J. Mead, R.J. Lucas, and K.M. Pollock. 1995. Process studies in a Pinus radiata-pasture agroforestry system in a subhumid temperature environment. II. Analysis of dry matter yields in the third year. Agrofor. Syst. 32:185-204. doi:10.1007/BF00711572 